\title{
Jones and Hawke make hay
}

\section{Canberra}

THE restructuring of Australian industry in the face of rapid technological change has become a central policy theme of the yearold Labor Government, due in large measure to the advocacy of the Minister for Science and Technology, Mr Barry Jones. The Prime Minister, Mr R.J. (Bob) Hawke, has set up a committee of federal ministers to coordinate policies relating to the many deep structural changes necessary. As well as Mr Jones, the committee includes the Ministers for Trade, Education and Youth Affairs, Industrial Relations and Defence Support, under the chairmanship of Senator John Button, Minister for Industry and Commerce.

On 13 April, Mr Jones released a draft national technology strategy to stimulate Australia-wide discussion of structural problems. His paper, a summary of deliberations of the National Technology Conference last September, contains several proposals crucial to the transformation of Australian productivity. It is particularly concerned with the minuscule investment in research and development by private industrial companies. According to the figures made available, research and development in Australia in 1981-82 hit a low of 1 per cent of gross national product (GNP), with the business sector's contribution sinking to 0.2 per cent. In 1968-69, private research and development was 0.5 per cent of GNP in a national total of 1.3 per cent.

The paper now sets a target of 1.5 per cent of GNP overall for 1990, with the business share amounting to 0.5 per cent and rising to 1.0 per cent by 1995 to equal the government's projected contribution.

Much of the blame for Australia's dismal export performance in technology was attributed to the country's attitude to education as an investment. The Jones strategy now urges that the proportion of Australian children completing secondary school be increased from 30 per cent in 1982 to 40 per cent in 1985 and 50 per cent by 1995. Alarmingly, the number of tertiary students between 17 and 22 years old actually fell, as a proportion of the population of the same age, from 11.5 per cent in 1975 to 10.5 per cent in 1982 . The strategy paper's recommended figures for 1985 and 1995 are 12 per cent and 20 per cent respectively.

Many of the recommendations in this paper are politically sensitive, including the proposal for a review of union attitudes to adult apprenticeships, the effect on training of minimum wages for juniors and the previously sacrosanct doctrine of "comparative wage justice" in which "'equal work" attracts equal pay regardless of the industry or its capacity to pay. One per cent of the workforce should be retrained each year, a portable super- annuation scheme instituted to promote mobility between industry, universities and government, and industrial protection gradually reduced.

In a society arthritic with structural rigidity, with 50 per cent of the workforce unionized and a cadre of industrial managers not yet weaned from protectionism, the issues canvassed are strong meat. The prosecution of the policy implied will depend on Mr Hawke's skill at maintaining consensus.

An admirer of South-East Asian industrial development and a recent convert to economic planning in the style of the Japanese Ministry of International Trade and Industry (MITI), he claims that previous governments have not been interested in formulating coherent science and technology policies.

Jeffrey Sellar

European pharmaceuticals Free trade makes trouble

A BRITish Medical Association (BMA) campaign aimed at preventing patients from being dispensed unlicensed drugs has suffered a temporary setback. The newlyformed Association of Pharmaceutical Importers claims that BMA's advice to physicians last week to stamp prescriptions "UK-licensed products only" contravenes the Treaty of Rome.

BMA's general medical services committee had become concerned by the growing number of reports of adverse reactions to imported drugs that are dispensed in the same ways as UK brands but which have not been licensed specifically for the UK market. Imported products bearing the same name as home lines may include differently coloured tab-

\section{Radioactive atolls}

\section{Bikini Islanders sue United States}

\section{Washington}

THE inhabitants of Bikini Island, which was used for 23 above-ground nuclear tests between 1946 and 1958, are suing the US Government in an attempt to force a cleanup of their homeland. The 167 residents of the island left at the request of the US military and have since been shifted several times to different nearby islands, living largely on food and supplies provided by the US Government.

A study commissioned by Congress reported last fall that a clean-up could be carried out at a cost of $\$ 90-120$ million.

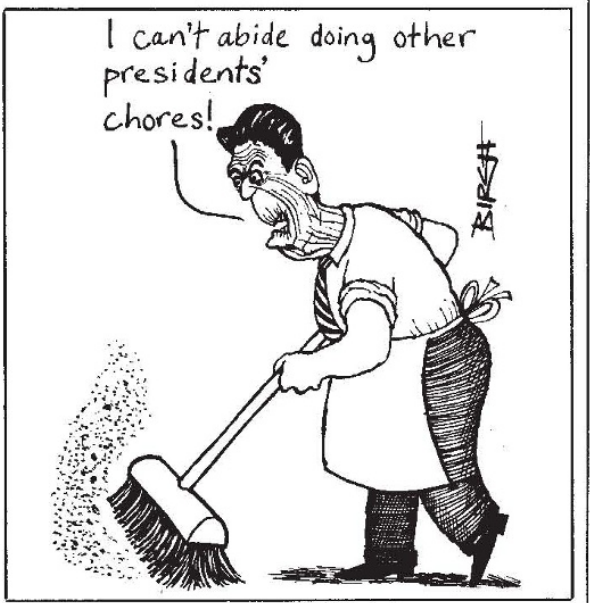

The most feasible approach, according to the study team headed by Harvard professor emeritus Henry Kohn, would be the removal of a million cubic metres of contaminated topsoil. Without such drastic measures, the island would not be habitable for 100 years if local foods were to be consumed.

The urgency of the suit filed this week, according to the islanders' attorney
Jonathan Weisgall, is that the Compact of Free Association approved by the Marshall Islanders (of which Bikini is a part) and now pending before Congress would terminate all claims arising out of the nuclear testing, and would provide no funds for cleaning up Bikini. The Bikini Islanders would, however, receive $\$ 75$ million in compensation over the next 15 years on top of the $\$ 23$ million trust fund already set-aside by Congress. This fund is used to pay medical and other expenses and a monthly stipend to the 1,100 islanders and their descendants.

Eniwetok, an island near Bikini also used for nuclear testing in the 1950s, was cleaned up by the United States in the 1970 s at a cost of $\$ 105$ million.

The Bikini atoll had been resettled after the Atomic Energy Commission (AEC) reported in 1967 that radiation had diminished to a safe level. In 1975, however, an initial ground radiological survey raised doubts about AEC's earlier conclusion; and a full survey in 1978, which included measurements of body-burdens of radiation in the $139 \mathrm{Bikini}$ Islanders who had returned, found that they were receiving exposures of 0.27 to $1.18 \mathrm{rem}$ per year, largely from eating locally-grown food that had taken up radioactive caesium-137 from the soil. The federal standard for the general public is $0.5 \mathrm{rem}$ per year; the occupational limit is 5 rem per year. Those who had resettled were removed once again, and the island has since remained uninhabited.

As well as taking legal action, the islanders are appealing to Congress for action on a clean-up; the House Interior Committee has recommended an initial $\$ 10$ million authorization to begin the work.

Stephen Budiansky 
lets and dosages, differently worded instructions (sometimes not in English) and may even be of different formulation or make-up. Its recommendation to physicians was intended to counter this trend.

BMA's advice is heartily endorsed by the Association of British Pharmaceutical Industry. British manufacturers estimate they lost $£ 75$ million last year to "parallel imports", bought from their overseas divisions and sold in Britain considerably below the standard British price. The price differentials are a consequence of the varied methods for regulating pharmaceutical companies in different countries. In Britain, overall profits are limited under the Pharmaceutical Prices Regulation Scheme, which specifies a target profit band for each company, based on capital expenditure. In other countries, prices or profits may be controlled individually for different products.

The European Court of Justice ruled in 1976 that parallel importing should be facilitated and that restrictions would be in breach of freedom of trade, but in 1980 an attempt by the commission to introduce a directive legitimizing parallel importing failed. The new pharmaceutical importers' association justifies its present imports by citing a British licences exemption order intended to apply "in circumstances in which small quantities of medicinal products are imported into the United employed, and also controls advertising

Kingdom for the treatment of particular patients".

Even though advertising of products imported under this order is illegal, the Department of Health has been unwilling to take action against infringements, fearing it would be dragged through the European Court. A new statutory instrument that will permit advertising of parallel imports and comply with the European Court's ruling while retaining some controls is now being finalized by the Department of Health and will be laid before Parliament in a few weeks' time.

A spokesman for the parallel importers accepted that British patients had in the past been dispensed products other than those their physicians intended, but said the association will encourage its members to "put their houses in order"'. Recently, some of its members were obliged to give an undertaking in the High Court to stop passing off as the UK version an imported Glaxo product with deliberately counterfeit packaging.

At issue now is whether a voluntary professional association such as BMA can make recommendations to its own members without contravening European law. BMA says it took full legal advice before making its recommendations to physicians and is confident of their legality. The question now seems likely to be answered in court, and BMA has halted its campaign until the issue is resolved to its satisfaction.

Tim Beardsley

\section{China in space}

\section{Triumph and martyrdom}

CHINA'S space planners last month released details of the setbacks and disasters suffered during the nine-year effort to put into synchronous orbit an "experimental" communications satellite. The satellite was successfully launched on 8 April, and inserted into its final orbit at $125^{\circ} \mathrm{E}$ on 16 April.

The admission on Chinese radio that a number of "scientific and technical workers" had "laid down their precious lives" during the development of the satellite was clearly intended as part of the current drive against "anti-intellectual" prejudice still persisting from the Cultural Revolution.

The broadcast centred on two major examples of heroism. One, a lone martyr, Ma Jungyan, had been working on the possible effects of solar radiation on a satellite in orbit. As this was during the "chaotic time of the Gang of Four", $\mathrm{Ma}$ was obliged to carry out simulated experiments at the atomic energy research institute without even the "minimum safety protection". He was, said the commentator, fully aware of the danger but "knowing that there was a tiger in the mountains, he still headed towards them"'. As a result, he developed a serious radiation-induced lung condition, but during every remission continued to "work frantically",

The other incident was the explosion of a rocket on 28 January 1978, during tests on fuel flow. Seven of the research team, including the director of the test-pad, were seriously injured and several others suffered burns and ruptured eardrums. Nevertheless, at the urging of the injured director, a party meeting was held the same afternoon to determine the cause of the incident, and testing was back to normal three days later. A week after the incident, the director and "several other comrades" were back at work, still in bandages, and they returned to the hospital to complete their treatment only when the experiment was finished.

It is not clear whether there were any deaths in this incident; the commentator clearly implied, however, that there had been several fatalities on what he called the "battlefield" of the space programme, the programme of the rocketry division. Whether Ma Jungyan and his fellow martyrs will receive public recognition in the forthcoming exhibition on the Chinese space programme, which opens in Shanghai later this month, has not yet been revealed. But China seems bent on being open.

\section{Unesco Looking for signs of change}

FURTHER signs of the response of Unesco (the United Nations Educational, Scientific and Cultural Organization) to the discontent of some member states should become apparent next week, at the meeting of the organization's executive board arranged for 9-23 May. Those participating in the meeting expect that decisions about the budget for 1985 , when the US notice of withdrawal will have expired, cannot be taken until the meeting of the executive board due in November. But next week's meeting should throw some light on Unesco's response to the British Government's for radical changes in the organization's way of working.

The agenda for next week's meeting concern's Unesco's science and technology sector only in uncontroversial ways - the executive board is expected to take on the nod the secretariat's proposals for the invitation lists to this November's meeting on information technology and that planned for next year on problems affecting Latin America and the Caribbean. Moreover, science and technology are relatively well protected in the secretariat's proposals for trimming $\$ 10$ million from the two-year budget for 1984-85. Indeed, the grant to the International Council of Scientific Unions has actually been increased.

Fireworks, if there are any, will rather attend the general items on next week's agenda, especially that requiring a first response to the British letter from $\mathrm{Mr}$ Timothy Raison, Minister of State at the Overseas Development Administration, sent to the director-general of Unesco in March. That letter asked that Unesco should reorder its priorities and improve the management of its affairs. At a later meeting in London, the director-general was told that continued British membership "could not be justified" unless there were signs of change at Unesco.

By all accounts, few expect that there will be much that is tangible to report from this first meeting of the executive board since the letter was sent, although the British will at least be looking for some mechanism by which their proposals can be studied seriously. But the responses of both the Unesco secretariat and the delegates of other member states are likely also to influence the spirit in which the British Government carries out its promised - or threatened - review of the benefits of membership.

Mr Ray Beverton, who succeeded Sir John Kendrew on 1 April as chairman of the science and technology subcommittee of the British National Committee on Unesco, said earlier this week that his group had not yet begun work in earnest on the task, but that a meeting had been arranged for May. 